\title{
Zinc Doped Hydroxyapatite Thin Films Prepared by Sol-Gel Spin Coating Procedure
}

\author{
Daniela Predoi ${ }^{1, *}$, Simona Liliana Iconaru ${ }^{1}$, Mihai Valentin Predoi ${ }^{2}$, Nicolas Buton ${ }^{3}$ and \\ Mikael Motelica-Heino ${ }^{4}$ \\ 1 National Institute of Materials Physics, Atomistilor Street, No. 405A, P.O. Box MG 07, \\ 077125 Magurele, Romania; simonaiconaru@gmail.com \\ 2 Department of Mechanics, University Politehnica of Bucharest, BN 002, 313 Splaiul Independentei, Sector 6, \\ 060042 Bucharest, Romania; predoi@gmail.com \\ 3 HORIBA Jobin Yvon S.A.S., 6-18, rue du Canal, 91165 Longjumeau cédex, France; nicolas.buton@horiba.com \\ 4 ISTO, UMR 7327 CNRS Université d'Orléans, 1A rue de la Férollerie, 45071 Orléans CEDEX 2, France; \\ mikael.motelica@univ-orleans.fr \\ * Correspondence: dpredoi@gmail.com; Tel.: +40-21-241-8154
}

Received: 30 January 2019; Accepted: 25 February 2019; Published: 28 February 2019

\begin{abstract}
In this study, ZnHAp layers deposited on a Si substrate were obtained by a sol-gel spin-coating procedure. The ZnHAp solutions used to obtain the ZnHAp coatings were investigated

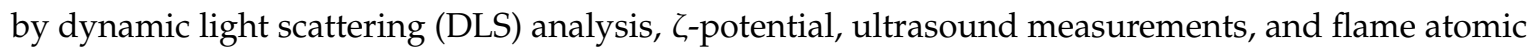
absorption spectrometry (AAS). The average measured hydrodynamic diameter from the DLS analysis, $\zeta$-potential, and ultrasound measurements were analyzed so as to characterize and estimate the stability of the ZnHAp nanoparticles. The AAS results confirmed the presence of zinc in the gels used in the preparation of the ZnHAp layers. The layers were investigated by $\mathrm{X}$-ray diffraction (XRD) and scanning electron microscopy (SEM). The XRD results revealed the diffraction peaks of the hexagonal hydroxyapatite in all of the investigated samples. The morphology of the ZnHAp coatings annealed at $500{ }^{\circ} \mathrm{C}$ (ZnHAp-500) and $700{ }^{\circ} \mathrm{C}$ (ZnHAp-700), which evidenced that no fissures or cracks formed on the surface of the coatings. The biocompatibility assays indicated that the ZnHAp coatings did not present any toxicity towards the HeLa cells. Furthermore, the study regarding the cytotoxicity of the ZnHAp layers against microorganisms emphasized that ZnHAp coatings exhibited an inhibitory effect towards $S$. aureus bacterial cells and also towards $C$. albicans fungal cells.
\end{abstract}

Keywords: zinc; hydroxyapatite; ultrasound measurement; sol-gel spin coating; layers; C. albicans; S. aureus

\section{Introduction}

Nowadays, the constant and rapid progress registered in the area of technology and engineering has created tremendous opportunities for modern medicine, by creating the premise of developing new and enhanced materials with outstanding properties that could greatly contribute to the improvement of a patient's life quality [1-3]. Nonetheless, even with the constant new developments, there are still difficulties to overcome for some issues in the biomedical field, as a result of medical devices, which could lead to post operatory complications [4]. These days, one of the most distressing complications that could appear after surgery is considered the apparition of a post operatory infection $[5,6]$. In most cases, the infection appears because of the bacterial cells, which adhere either to an implantable medical device (when is the case), either on the tissue surrounding the surface of the implant, or simply on the surface of the wound $[7,8]$. These types of bacterial adhesions on implantable devices are some of the most frightening problems that can occur in the dentistry, orthopedic, and cardiovascular field, because they usually lead to severe life treating infections due to the development 
of bacterial biofilms, which have been proven to be resilient to conventional antibiotics [9-13]. In most cases, because of the development of bacterial infections, implantable devices are often removed from patients using many costly procedures, which are uncomfortable and even dangerous for the patient [14]. Considering these factors, there has been an increased effort directed towards the development of new materials capable of mimicking the composition and structure of bone, also exhibiting antimicrobial properties [15-17]. Commonly, one of the widely used biomaterials, due to its outstanding biocompatible and osteoconductive properties, is hydroxyapatite (HAp). Synthetic HAp, with the general formula $\mathrm{Ca}_{10}\left(\mathrm{PO}_{4}\right)_{6}(\mathrm{OH})_{2}$, has been widely studied for bone substitution, bone remodeling applications, controlled drug release, bone tissue engineering, bone regeneration as bone graft materials, coatings for implants, or bone fillers [16-18]. Nowadays, HAp is used both in reconstruction and repair surgery, as well as in conservative dentistry, dental implantology, and pharmacy $[19,20]$. Used as an implant coating, synthetic HAp has been studied because of its excellent biocompatibility and osteoconductivity $[20,21]$. Despite its great potential, HAp has limitations because of its poor mechanical properties (brittleness, poor tensile strength, and poor fatigue strength) [22,23] and slow biological interaction, and it is because of these factors, which favor the adherence and development of bacterial cells, that the apparition of post operatory infections is caused. Nevertheless, numerous studies have reported that the properties of HAp could be improved by doping with various elements such as $\mathrm{Na}, \mathrm{Sr}, \mathrm{Mg}, \mathrm{K}, \mathrm{Mn}, \mathrm{Ag}, \mathrm{Ce}, \mathrm{Eu}, \mathrm{Cu}, \mathrm{Zn}, \mathrm{Sm}$, and so on [24-27]. The structure of HAp allows for both anionic and cationic substitutions [24-27]. Zinc is one of the most widespread trace elements, and is usually considered as a potential substituent in HAp because of its biological properties [28]. Taking into account that almost a third of the amount of zinc that is found in the human body is located in bone tissue, and also that zinc contributes to the proliferation of osteoblast cells and enhances the bone formation process $[27,28]$, the use of zinc as a doping element for HAp will create the premise of obtaining a new biomaterial with outstanding biological properties. Recent studies have also reported that zinc possesses antimicrobial properties and could be used in the development of antimicrobial agents [29-32]. In their study, Radovanović et al. [33] highlighted that zinc exhibited a good antimicrobial activity against Staphylococcus aureus, Escherichia coli, Pseudomonas aeruginosa, and Candida albicans microbial strains [33].

Over the years, extensive research has been conducted for the development of uniform, reproducible, and reliable layers using various advanced deposition techniques [34-37]. There are many papers dealing with thin film development, involving several techniques such as vacuum evaporation [38], sputtering [36], laser-assist vacuum evaporation [38], chemical bath deposition [39], electrodepositing [40], dip coating [41], sol-gel [42], the Langmuir Blodgett technique [43], and so on. Among these, the sol-gel spin coating technique is considered to be one of the simplest and most cost-effective techniques for thin film deposition [44]. It has been reported that by using the conventional spin coating technique, the material parameters can be used to determine the final film thickness, which is considered to be a tremendous advantage when developing thin films [45].

The present study is focused on developing ZnHAp coatings based on stable solutions with applications in the biomedical field. Firstly, stable solutions of ZnHAp have been synthesized and characterized. The ZnHAp solutions have been studied using dynamic light scattering (DLS), Zeta potential, and atomic absorption spectroscopy (AAS). On the other hand, studies regarding the stability of the resulting ZnHAp solutions obtained by the sol-gel method were performed using ultrasound measurements. Afterwards, the ZnHAp coatings were deposited on Si discs. The ZnHAp coatings were investigated by $\mathrm{X}$-ray diffraction (XRD) and scanning electron microscopy (SEM). The cytotoxicity of the ZnHAp coatings was studied using a HeLa cell line. Moreover, the antimicrobial activity of the ZnHAp coatings was investigated against Candida albicans ATCC 10231 and Staphylococcus aureus ATCC 25923 microbial strains. 


\section{Materials and Methods}

\subsection{Materials}

Reagents such as calcium nitrate $\left(\mathrm{Ca}\left(\mathrm{NO}_{3}\right)_{2} \cdot 4 \mathrm{H}_{2} \mathrm{O}\right.$, Sigma-Aldrich, St. Louis, MA, USA), ammonium hydrogen phosphate $\left(\left(\mathrm{NH}_{4}\right)_{2} \mathrm{HPO}_{4}\right)$, Alfa Aesar, Karlsruhe, Germany; $99.99 \%$ purity), silver nitrate $\left(\mathrm{Zn}\left(\mathrm{NO}_{3}\right)_{2} \cdot 6 \mathrm{H}_{2} \mathrm{O}\right.$, Alfa Aesar, Karlsruhe, Germany; 99.99\% purity), triethanolamine $\left(\mathrm{C}_{6} \mathrm{H}_{15} \mathrm{NO}_{3}\right.$, Sigma-Aldrich; $\geq 99.0 \%$ (GC) purity), and ethanol were used for obtaining the zinc doped hydroxyapatite (ZnHAp) solutions using the sol-gel method, in order to prepare the ZnHAp coatings on the Si substrate using the spin-coating procedure.

\subsection{Thin Layer of Zinc Doped Hydroxyapatite}

Calcium nitrate $\left(\mathrm{Ca}\left(\mathrm{NO}_{3}\right)_{2} \cdot 4 \mathrm{H}_{2} \mathrm{O}\right)$, zinc nitrate $\left(\mathrm{Zn}\left(\mathrm{NO}_{3}\right)_{2} \cdot 6 \mathrm{H}_{2} \mathrm{O}\right)$, and ammonium hydrogen phosphate $\left(\left(\mathrm{NH}_{4}\right)_{2} \mathrm{HPO}_{4}\right)$ were used as the starting materials for the preparation of zinc doped hydroxyapatite $\left(\mathrm{Ca}_{10-x} \mathrm{Zn}\left(\mathrm{PO}_{4}\right)_{6}(\mathrm{OH})_{2}, x_{\mathrm{Zn}}=0.1\right)$ thin layers on an Si substrate $(\mathrm{ZnHAp})$, respectively. In order to synthesize the zinc doped hydroxyapatite gel for preparing the thin layers, triethanolamine $\left(\mathrm{C}_{6} \mathrm{H}_{15} \mathrm{NO}_{3}\right)$ and ethanol $\left(\mathrm{C}_{2} \mathrm{H}_{5} \mathrm{OH}\right)$ were also used. $\mathrm{Ca}\left(\mathrm{NO}_{3}\right)_{2} \cdot 4 \mathrm{H}_{2} \mathrm{O}$ was dissolved in ethanol and mixed on a magnetic stirrer for $120 \mathrm{~min}$ at $40{ }^{\circ} \mathrm{C}$. Triethanolamine was slowly dripped into the solution containing $\mathrm{Ca}$, and the solution was agitated vigorously for $24 \mathrm{~h}$ at $40^{\circ} \mathrm{C}$. At the same time, $\left(\mathrm{NH}_{4}\right)_{2} \mathrm{HPO}_{4}$ and $\left.\mathrm{Zn}\left(\mathrm{NO}_{3}\right)_{2} \cdot 6 \mathrm{H}_{2} \mathrm{O}\right)$ were dissolved in the ethanol and mixed on a magnetic stirrer for $120 \mathrm{~min}$ at $40{ }^{\circ} \mathrm{C}$. Next, the solution containing Ca was slowly added to the solution containing $\mathrm{P}$ and $\mathrm{Zn}$. The final solution was constantly agitated on a magnetic stirrer for $6 \mathrm{~h}$ at $100{ }^{\circ} \mathrm{C}$. According to the authors of [18], in the ZnHAp $\left(x_{\mathrm{Zn}}=0.1\right)$ sol, $[\mathrm{Ca}+\mathrm{Zn}] / \mathrm{P}$, the composition ratio was adjusted to be equal to 1.67. The resulting gel was mixing by ultrasound for $6 \mathrm{~h}$. The resulting sol-gel solution was used to obtain, using the spin-coating procedure, the ZnHAp coatings on the Si substrate. For the centrifugation coating, $0.5 \mathrm{~mL}$ of the resulting solution was placed on the top of the substrate using a syringe. The centrifugation was carried out for $60 \mathrm{~s}$ at $2000 \mathrm{rpm}$. The Si substrates were repeatedly coated 30 (ZnHAp) times. The Zn:HAp layers were annealed for $2 \mathrm{~h}$ at $500{ }^{\circ} \mathrm{C}(\mathrm{ZnHAp}-500)$ and $700{ }^{\circ} \mathrm{C}$ (ZnHAp-700), in order to remove the solvents and to obtain films with a crystalline structure.

\subsection{Characterization Methods}

The resulting sol-gel solution that was used to obtained the ZnHAp coatings on the Si substrate by the spin-coating procedure was investigated by dynamic light scattering (DLS) analysis, $\zeta$-potential, and ultrasound measurements. Dynamic light scattering (DLS) and $\zeta$-potential were performed at $25 \pm 1{ }^{\circ} \mathrm{C}$ using a SZ-100 Nanoparticle Analyzer (Horiba, Ltd., Kyoto, Japan. All of the samples were diluted in ethanol before analysis 10 times before the measurements of the DLS and $\zeta$-potential. Three determinations were recorded for each analyzed sample, and the final value was established by mediating the three measurements.

The sample was stirred for $30 \mathrm{~min}$ at room temperature. Then, the ultrasonic tests were effectuated using the setup indicated in Figure 1. There are two coaxial ultrasonic transducers distanced by $d=30 \mathrm{~mm}$, of a $5 \mathrm{MHz}$ central frequency, model H5K (General-Electric, Krautkramer, Hürth, Germany), one (marked R) sending and receiving the echoes, and the other (marked T) just receiving the echoes. These were the general purpose longitudinal non-focusing transducers, which attenuated the received echoes by different amounts at different frequencies. In order to minimize the losses in the transducers, we investigated only the echoes received by the $\mathrm{T}$ transducer at $5 \mathrm{~s}$ intervals. 


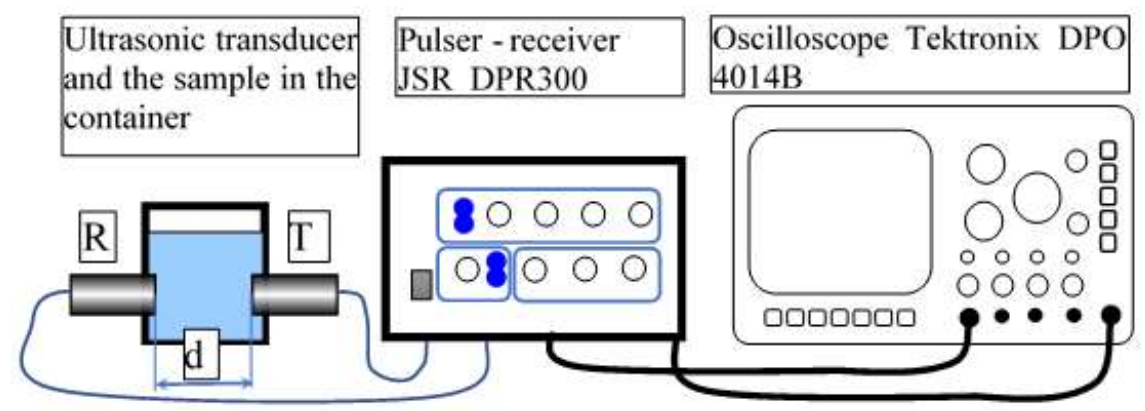

Figure 1. Experimental setup schematic: transducer, pulser-receiver, and oscilloscope.

Quantitative studies regarding the elemental composition of the new zinc-doped hydroxyapatite solutions were performed by flame atomic absorption spectrometry (AAS). The analysis was performed using a Zeeman HITACHI Z-8100 from Japan Hitachi (Tokyo, Japan), using a cavity cathode lamp, specific to the zinc element. The AAS investigations were done using stable solutions of ZnHAp. The AAS measurements were conducted using a zinc hollow cathode lamp under a constant airflow rate of $10.00 \mathrm{~L} \cdot \mathrm{min}^{-1}$, at a wavelength of $213.9 \mathrm{~nm}$, according to the manufacturer's operational conditions for zinc.

The resulting sol-gel solution that was used to obtained the ZnHAp coatings on the Si substrate by the spin-coating procedure were dried for $72 \mathrm{~h}$ at $100{ }^{\circ} \mathrm{C}$, and preseed into pellets in order to be investiagted by laser ablation-inductively coupled plasma-mass spectrometer (LA-ICP-MS). The studies were conducted in agreement with the procedure described by Motelica-Heino and Donard [46], using an elemental XR Thermo Specific instrument (Waltham, MA, USA) combined with a UV laser probe laser ablation sampling device (Teledyne CETAC Technologies, Omaha, NE, USA). The calibration was done with certified artificial glass, NIST-610. The measurements were reproduced four times.

The morphology of the samples was investigated by scanning electron microscopy (SEM), using a HITACHI S4500 microscope (Hitachi, Ltd., Tokyo, Japan) equipped with an X-ray energy dispersive spectroscopy (EDX) system. In order to establish the crystal structures of the ZnHAp layers, the XRD patterns were recorded using a Bruker D8 Advance diffractometer (Bruker, Karlsruhe, Germany) with a nickel filtered $\mathrm{Cu} \mathrm{K} \alpha(\lambda=1.5418 \AA)$ radiation in the $2 \theta$ ranging from $20^{\circ}$ to $55^{\circ}$.

\subsection{In Vitro Antifungal Activity}

The antimicrobial properties of the ZnHAp-500 and ZnHAp-700 layers were assessed using Candida albicans ATCC 10231 and Staphylococcus aureus ATCC 25923 microbial cells. The evaluation of the antimicrobial activity of the ZnHAp-500 and ZnHAp-700 layers was performed using $1.5 \times 10^{8}$ microbial suspensions of a $0.5 \mathrm{McF}$ arland standard obtained from 15 to $18 \mathrm{~h}$ bacterial cultures.

The qualitative antifungal and antibacterial activity of the layers was quantified at 24 and $48 \mathrm{~h}$. For this purpose, microbial suspensions of C. albicans ATCC 10231 and Staphylococcus aureus ATCC 25923 $(500 \mu \mathrm{L})$ were grown on the samples in culture medium. After 24 and $48 \mathrm{~h}$ the layers were removed from the culture medium, washed with sterile saline solution for the removal of the non-adherent microbial cells. The layers were then introduced into sterile saline $(1 \mathrm{~mL})$, vortexed for suspending the microbial cells embedded in the biofilm formed on the surface, washed in saline solution, fixed in cold methanol, and prepared for scanning electron microcopy (SEM) visualization.

The quantitative assays of the antimicrobial activity of the ZnHAp-500 and ZnHAp-700 layers were performed using an adapted method derived from the standard test method for determining the antimicrobial activity of antimicrobial agents under dynamic contact conditions (E2149-10; ASTM International) $[47,48]$. The layers were added in a Luria-Bertani (LB) broth inoculated with microbial suspensions of $1.5 \times 10^{8} \mathrm{CFU} / \mathrm{mL}$. The samples were allowed to incubate at $30{ }^{\circ} \mathrm{C}$ for four time intervals $(8,24,32$, and $48 \mathrm{~h})$ in order to assess the temporal dynamics of the microbial biofilms 
developed in the presence of the layers. After the incubation of each time interval, the HAp, ZnHAp-500, and ZnHAp-700 layers were removed from the medium, washed using a sterile saline buffer in order to remove the microbial cells that did not adhere to the substrates, and were then immersed in a sterile saline buffer. The quantitative assessment of the antimicrobial activity of the ZnHAp-500 and ZnHAp-700 layers was determined by measuring the absorbance of the recovered suspensions at $620 \mathrm{~nm}$. The experiments were performed in triplicate.

\subsection{Hela Cell Viability Assays}

The cell viability assays were performed using the first immortal human cell line, known for being one of the most remarkably durable and prolific cell lines (HeLa cells). HeLa cell growth assays were performed as previously described [49], with the following modifications: HeLa were grown in Dulbecco's modified Eagle's medium previously supplemented with fetal calf serum (FCS) $10 \%$, and with $2 \mathrm{mM}$ L-glutamine (GIBCO BRL, Life Technologies, Carlsbad, CA, USA) at a temperature of $37{ }^{\circ} \mathrm{C}$ in a humidified atmosphere with $5 \% \mathrm{CO}_{2}$. The culture medium was then renewed every 2 to 3 days. Then, the HeLa cells were seeded in six-well plates, at a density of $5 \times 10^{5}$ cells $/ \mathrm{mL}$, and incubated on previously UV-sterilized ZnHAp layers. The cell viability was assessed by microscopic evaluation after 24 and $48 \mathrm{~h}$ of incubation. Moreover, a quantitative assay regarding the cell viability was performed on the HeLa cells $\left(\sim 10^{4}\right.$ cells $\left./ 100 \mu \mathrm{L}\right)$ using the conventional 3-(4,5-dimethylthiazolyl-2)-2,5-diphenyltetrazolium bromide (MTT) reduction assay.

\subsection{Statistical Analysis}

All of the biological investigations were carried out in triplicate. The statistical analysis was carried out using the $\mathrm{t}$-test and analysis of variance (ANOVA). The difference established between the samples was appreciated to be significant at $p<0.05$.

\section{Results and Discussions}

\subsection{Characterization of Suspension}

To achieve uniform coatings, the gels obtained should be stable, and the nanoparticles should be

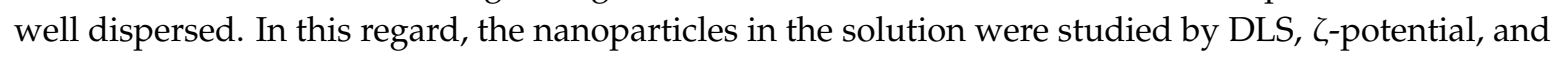
ultrasound measurements. If in the DLS studies and zeta potential the final gel was diluted 10 times, the ultrasound measurements allowed for the study of ZnHAp nanoparticles in the final concentrated solution obtained from the sol-gel synthesis method. In agreement with previous studies conducted by Egelhaaf et al. [50], DLS can be used to characterize the hydrodynamic diameter distribution in the range of some hundreds of $\mathrm{nm}$. These results provide important information on colloidal agglomeration. The hydrodynamic diameter distribution determined by DLS is shown in Figure 2. As shown in Figure 2A, the size of the particles was in the range of 10-60 nm. The average hydrodynamic diameter estimated from the hydrodynamic diameter distributions obtained by DLS was $45 \pm 4 \mathrm{~nm}$. One distinctive curve was visualized and coincided with one population that could indicate the lack of aggregates in the analyzed solution. The absence of agglomerates is also explained by the high potential of the $\zeta$-potential (Figure 2B,C).

The $\zeta$-potential value of the $\mathrm{ZnHAp}\left(x_{\mathrm{Zn}}=0.1\right)$ nanoparticles in the solution (Figure $\left.2 \mathrm{~B}\right)$ was $-45.8 \mathrm{mV}$. The value of the average electrophoretic mobility was $-0.00034 \mathrm{~cm}^{2} \mathrm{~V}^{-1} \mathrm{~s}^{-1}$ (Figure $2 \mathrm{C}$ ). The value obtained for the $\zeta$-potential in the ZnHAp gel was much higher than which has been reported so far $[19,31]$. This difference may be due to increasing the zinc concentration, and, on the other hand, to the synthesis parameters. In previous studies, Predoi et al. showed that for ZnHAp solutions with $0.01<x_{\mathrm{Zn}}<0.05$, the zeta potential increased from $-8.19 \mathrm{mV}\left(x_{\mathrm{Zn}}=0.01\right)$ to $-15.84 \mathrm{mV}$ when $x_{\mathrm{Zn}}$ was 0.05 . 
Significant information about the Zn:HAp gel used to prepare the ZnHAp layers were achieved from the ultrasound measurements. During the ultrasonic measurements, the recording time was $1000 \mathrm{~s}$, corresponding to 200 records, with each record containing 100k samples (Figure 3).
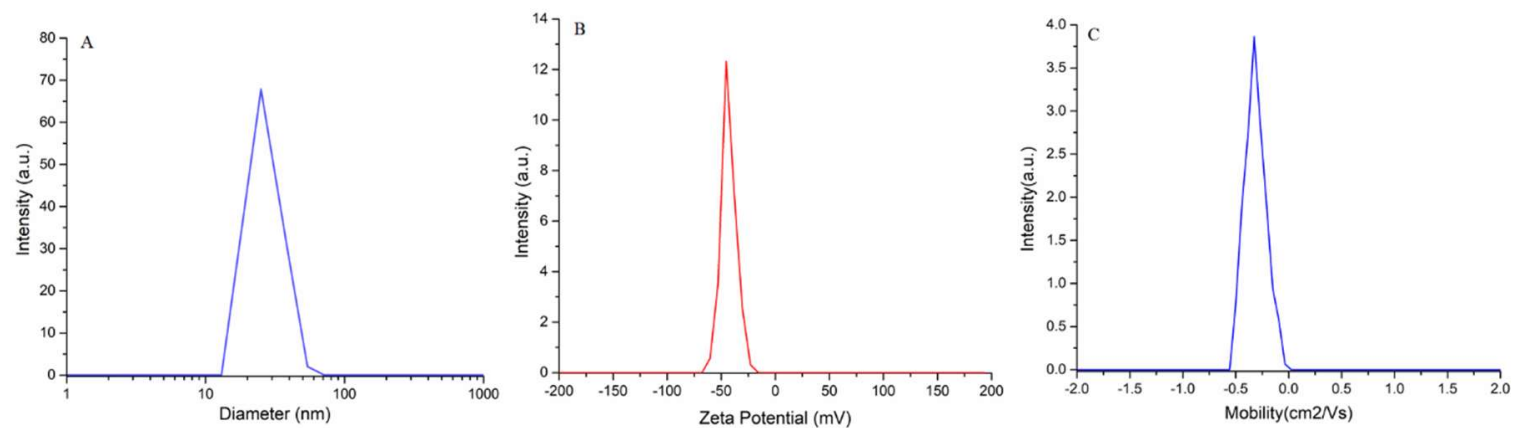

Figure 2. Colloidal characteristics of the $\mathrm{ZnHAp}$ and $\mathrm{Ca}_{10-x} \mathrm{Zn}_{x}\left(\mathrm{PO}_{4}\right)_{6}(\mathrm{OH})_{2}$ nanoparticles in the solution $\left(x_{\mathrm{Zn}}=0.1\right)$ : (A) hydrodynamic diameter distribution curves images; (B) $\zeta$-potential distribution curve; and (C) electrophoretic mobility.

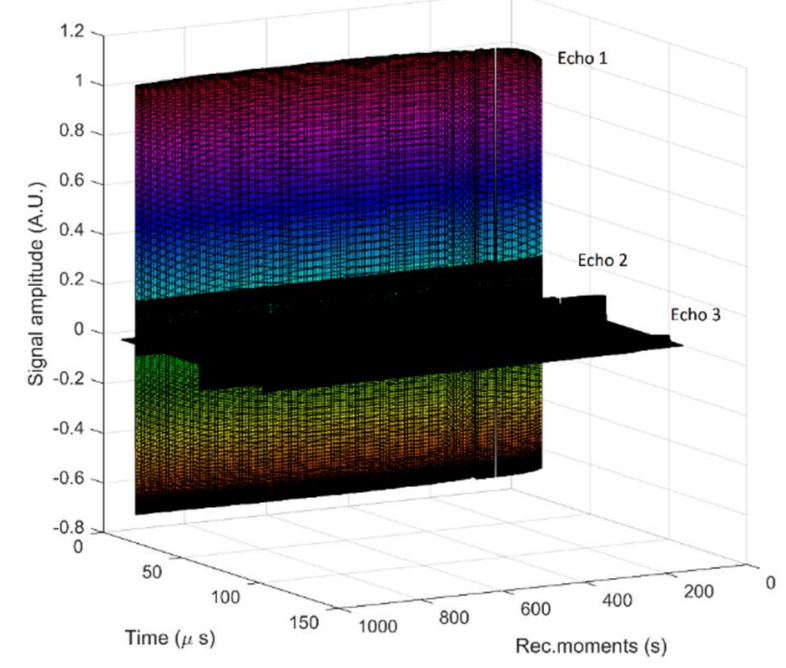

Figure 3. Recorded T signals for 1000 s. Each signal includes three echoes.

The three echoes obtained for the ZnHAp sample were each compared with the corresponding echoes in double distilled water in the same setup. This method allows for relative quantitative measurements, which eliminate the influence of the transducers attenuation and frequency spectrum.

Through the intercorrelation of each echo with the corresponding echo in the reference fluid, for which the velocity is $c_{0}=1489.23 \mathrm{~m} / \mathrm{s}$ at $22.3^{\circ} \mathrm{C}$, an average velocity in the sample of $c_{\mathrm{s}}=1489.1 \mathrm{~m} / \mathrm{s}$ has been deduced. The velocity of the ultrasonic waves in homogeneous liquids can be calculated with the relation $c=\sqrt{\frac{1}{\kappa \rho}}$, where the adiabatic compressibility, $k$, is the inverse of the compression elastic modulus $(K=1 / k)$, and $\rho$ is the averaged mass density. For the biphasic suspensions, the averaged values can be obtained from the following: $\kappa=\Phi \kappa_{2}+(1-\Phi) \kappa_{1}$ and $\rho=\Phi \rho_{2}+(1-\Phi) \rho_{1}$, in which $\Phi$ represents the volumetric fraction of the solid particles in the solvent, which was double distilled water in this case.

Consequently, if the volumetric fraction is known, and the elastic properties of the solvent are known (e.g., for water, $\left.\kappa=4.54 \times 10^{-10} \mathrm{~Pa}^{-1}\right)$, one can determine the pairs $\left(\kappa_{2}, \rho_{2}\right)$ of the particles in the suspension, and if one of the two parameters is known, then the other can be accurately determined.

The first information is the evolution in time of the echo's amplitudes (Figure 4A). The three recorded signals indicate the stable level of the amplitude, in direct connection with the physical stability of the sample. In our previous studies [24] on bioceramic layers with antifungal properties, we 
suggested a stability parameter, measured in $\mathrm{s}^{-1}$ and defined as $s=\frac{1}{A_{m}}\left|\frac{\mathrm{d} A}{\mathrm{~d} t}\right|$. The stability coefficient for this sample is $s=0.0152(1 / s)$, indicating a relatively stable suspension, compared with pure water, for which $s=0$.
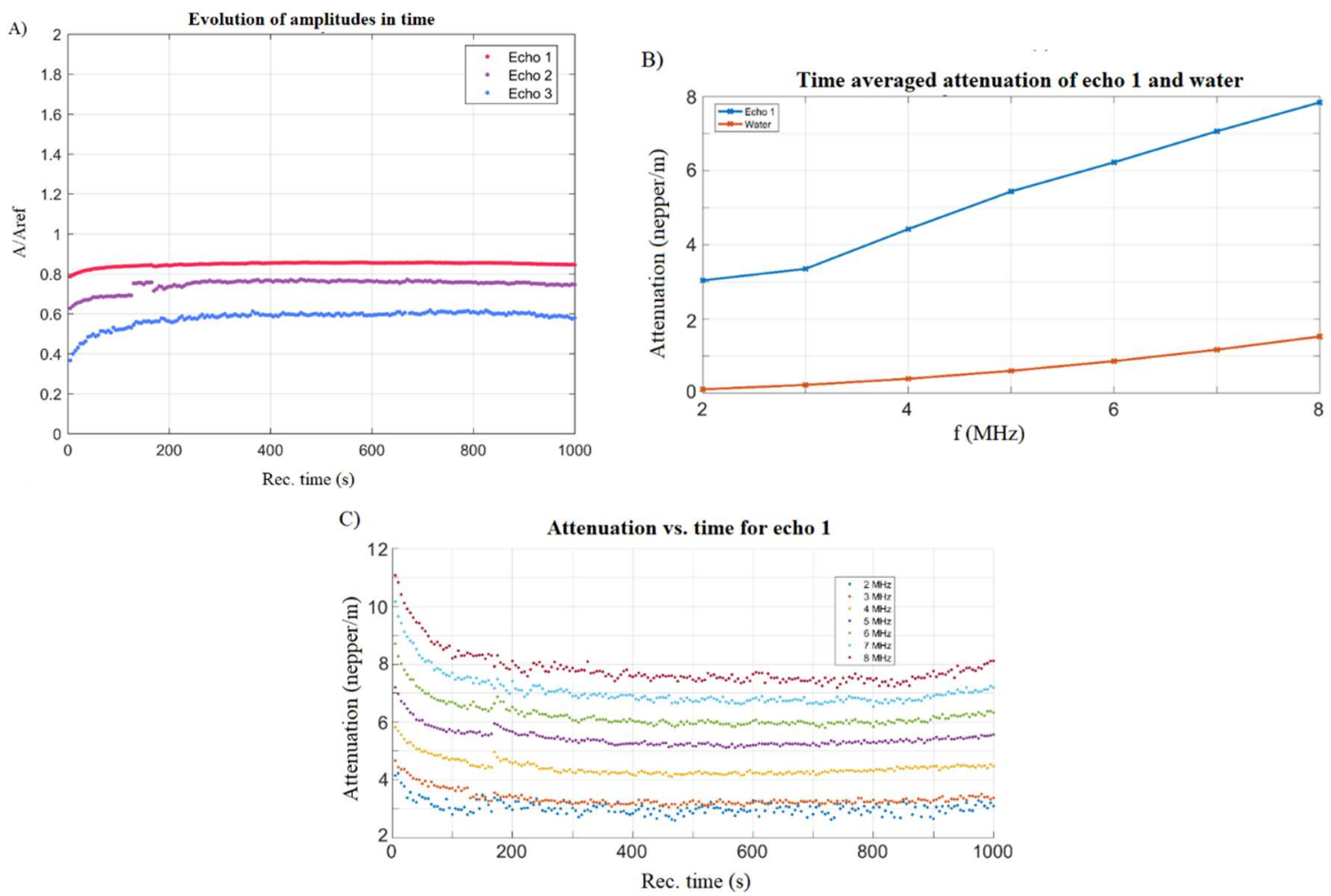

Figure 4. Evolution in time of the echoes amplitudes (A), spectral attenuation of echo 1 and reference fluid (B), and spectral attenuation vs. time for echo 1 (C).

There was an initial period of approximately $100 \mathrm{~s}$ during which the suspension reached a stable configuration. The second and third echoes have weaker amplitudes as a result of the attenuation, which will be discussed in the following. The following analysis concerns only the first echo, which was the least affected by the attenuation characteristics of the transducers.

The amplitudes at higher frequencies diminished, a phenomenon that is typical to ultrasound waves. However, this amplitude reduction vs. frequency is typical for each sample. For each echo, an averaged ratio of amplitudes at each frequency in the spectrum, relative to the reference fluid, were determined. The attenuation vs. frequency for the first echo is plotted in Figure 4B.

The attenuation is defined for two successive echoes of amplitudes, $A_{1}$ and $A_{2}$, determined after traveling a distance, $d$, as follows: $\alpha=-\frac{1}{d} \ln \frac{A_{2}}{A_{1}} \quad[\mathrm{~Np} / \mathrm{m}]$. For the reference fluid, the attenuation is known from the specialized literature and the attenuation of the sample is determined experimentally.

The attenuation in the sample is considerably higher than in the reference fluid, varying from $3.03 \mathrm{~Np} / \mathrm{m}$ at $2 \mathrm{MHz}$, up to $7.84 \mathrm{~Np} / \mathrm{m}$ at $8 \mathrm{MHz}$. The slope given by the stability parameter is also very important. For this sample, a change in the attenuation slope for frequencies above $3 \mathrm{MHz}$ is clearly visible, a fact related to the size and concentration of the nanoparticles. More details can be obtained by analyzing the evolution in time of the attenuation for each of the frequencies marked on Figure 4B. The results are plotted on Figure $4 \mathrm{C}$.

There was an initial period of about $100 \mathrm{~s}$, during which the attenuation decreased rapidly, possibly due the sedimentation of the larger size particles in the suspension. Between 100 and $900 \mathrm{~s}$, the attenuation at all of the frequencies remained relatively constant, proving the stability of the suspension. As shown on Figure 4B, the attenuation increased with the increasing frequency. 
The amount of zinc incorporated in the HAp lattice from the ZnHAp samples was investigated using flame atomic absorption spectrometry (AAS). For this purpose, stable solutions of ZnHAp were measured and the zinc concentration determined. The results of the AAS investigation revealed that the zinc concentration from the measured samples was of $1.785 \pm 2.5 \mathrm{wt} \%$.

More than that, ICP-MS investigations were performed on the ZnHAp powders obtained from the sol-gel solution used in the spin-coating procedure. The results of the ICP-MS studies revealed that the amount of zinc from the ZnHAp powders calculated from the ICP measuremets was $1.57 \pm 1.8 \mathrm{wt} \%$. These results are both in good agreement with previous studies reported by Predoi et al. [19].

\subsection{Structure and Morphology of the Layers}

The XRD patterns of the ZnHAp layers deposited on the Si substrates using the sol-gel spin coating method are shown in Figure 5. The XRD analysis was used for determining the phase composition of the layers. The XRD patterns of the ZnHAp layers deposited on the Si substrates using the sol-gel spin coating method are shown in Figure 5.

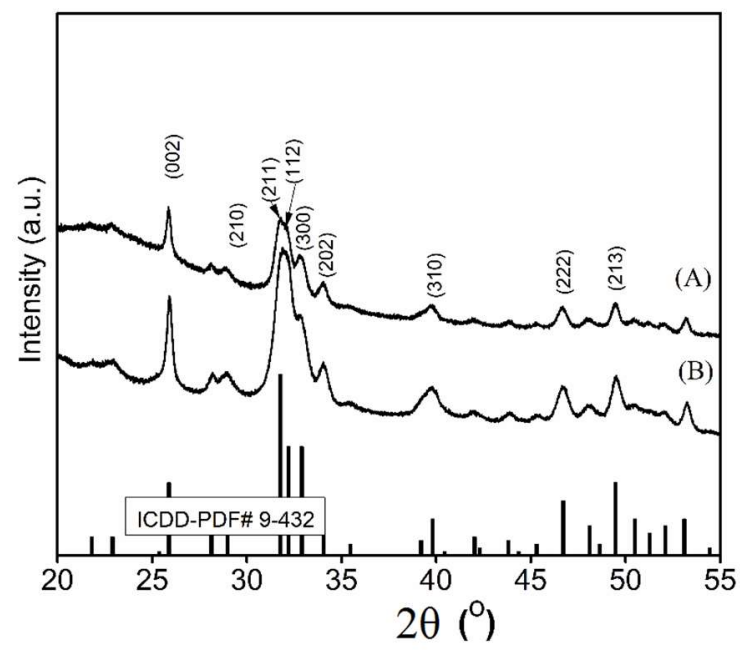

Figure 5. XRD pattern of the ZnHAp layers annealed at $500{ }^{\circ} \mathrm{C}(\mathbf{A})$ and $700{ }^{\circ} \mathrm{C}(\mathbf{B})$.

The influence of the annealing temperature on the coating was clearly seen. The peak broadening of the HAp samples decreased upon increasing the temperature, indicating that the crystallinity increased. The XRD patterns revealed the diffraction peaks of hexagonal HAp (space group P63/m) in all of the layers (A and B) according to a standard card of the HAp (ICDD-PDF \#9-0432). The relative $2 \theta$ position of the diffraction peaks remained virtually unchanged with respect to the application temperatures, up to $700{ }^{\circ} \mathrm{C}$. No impurity peaks of metallic $\mathrm{Zn}$ were detected in the XRD patterns. On the other hand, the peaks at about $31^{\circ}$ and $47^{\circ}(2 \theta)$, which are characteristic of an amorphous phase, were not observed [51]. The XRD patterns of the ZnHAp-500 and ZnHAp-700 annealed samples revealed two peaks located at $31.7^{\circ}$ and $46.7^{\circ} 2 \theta$, which correspond to the (211) and (222) reflection plans of the hexagonal hydroxyapatite [52]. The results of the XRD studies of the ZnHAp-500 and ZnHAp-700 layers were in good agreement with the previous studies [52].

In order to determine the surface morphology of the ZnHAp-500 and ZnHAp-700 layers, SEM analysis was used. The SEM images of the ZnHAp-500 and ZnHAp-700 layers are presented in Figure 6A,B. The SEM analysis of the coatings did not reveal the pits and fissures on the surface of the ZnHAp-500 and ZnHAp-700 samples. In order to confirm that there were no cracks on the layers' surfaces in Figure 6C,D, the lower magnification images for the investigated samples are presented. Moreover, luminous areas corresponding to the surface of the Si substrate have not been observed. Although, in both cases, a dense layer with a homogeneous structure was observed, but the coating morphology of the surface samples was slightly different. This was due to the higher temperature at 
which the heat treatment was carried out. The SEM analysis of the transversal cross section of the investigated layers indicated a thickness equal to $140.1 \mathrm{~nm}$ for ZnHAp-500 (Figure 6E), and $138.6 \mathrm{~nm}$ for ZnHAp-700 (Figure 6F).

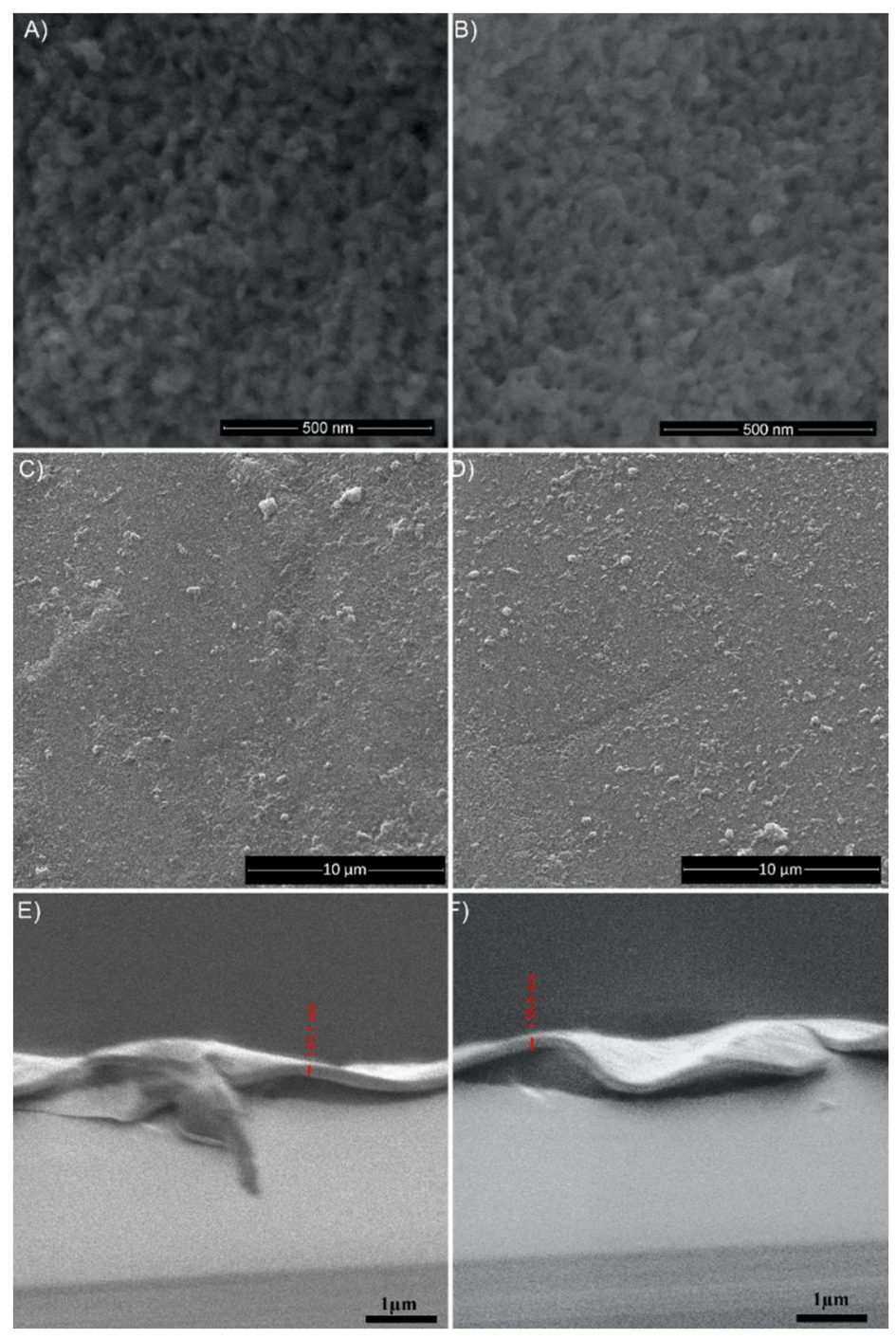

Figure 6. SEM images of the ZnHAp-500 (A,C) and ZnHAp-700 (B,D) layers at different magnifications. SEM images of the transversal cross section of ZnHAp-500 (E) and ZnHAp-700 (F) layers.

\subsection{Cell Viability}

Figure 7A-C shows the morphology of the HeLa cells treated with at $24 \mathrm{~h}$. The morphology of the HeLa cells treated with ZnHAp-500 (Figure 7E) and ZnHAp-700 (Figure 7F) at $48 \mathrm{~h}$ are presented in Figure 7E,F. The morphology and size of the HeLa cells did not change after their treatment at 24 and $48 \mathrm{~h}$, relative to the control. The control cells at 24 (Figure 7A) and $48 \mathrm{~h}$ (Figure 7D) were represented by HeLa cells grown in the culture medium. MTT assay was used to verify the cell viability of the HeLa cells for incubation times of 24 and $48 \mathrm{~h}$, in presence of ZnHAp-500 and ZnHAp-700 layers. In Figure 8 , the percentages of the cell viability are. The cell viability values for the ZnHAp-500 sample were observed to be about $88 \%$ and $92 \%$ at 24 and $48 \mathrm{~h}$, respectively, relative to the control. The cell viability values for the ZnHAp-700 sample were observed to be about $90 \%$ and $95 \%$ at 24 and $48 \mathrm{~h}$, respectively. The obtained results for the MTT assay revealed that as the annealing temperature of the layers increased and the incubation time increased, the cell viability gradually increased. 

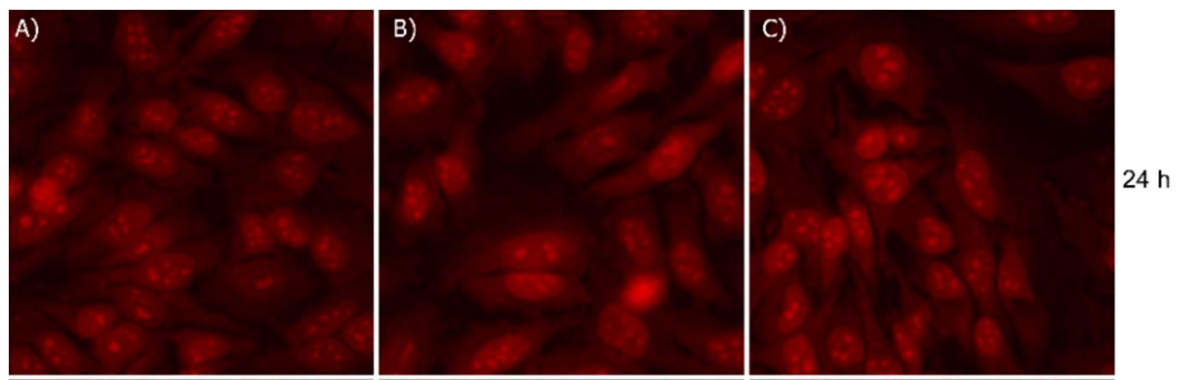

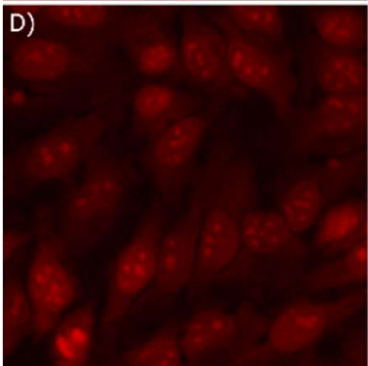

Control

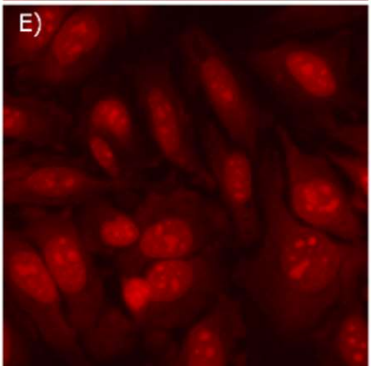

ZnHAp-500

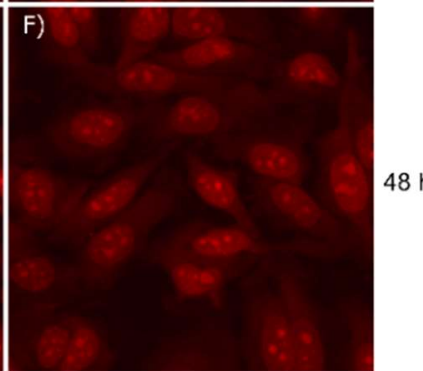

ZnHAp-700

Figure 7. The morphology of the HeLa cells treated with ZnHAp-500 (B) and ZnHAp-700 (C) at $24 \mathrm{~h}$, relative to the control (A). The morphology of the HeLa cells treated with ZnHAp-500 (E) and ZnHAp-700 (F) at $48 \mathrm{~h}$, relative to the control (D).

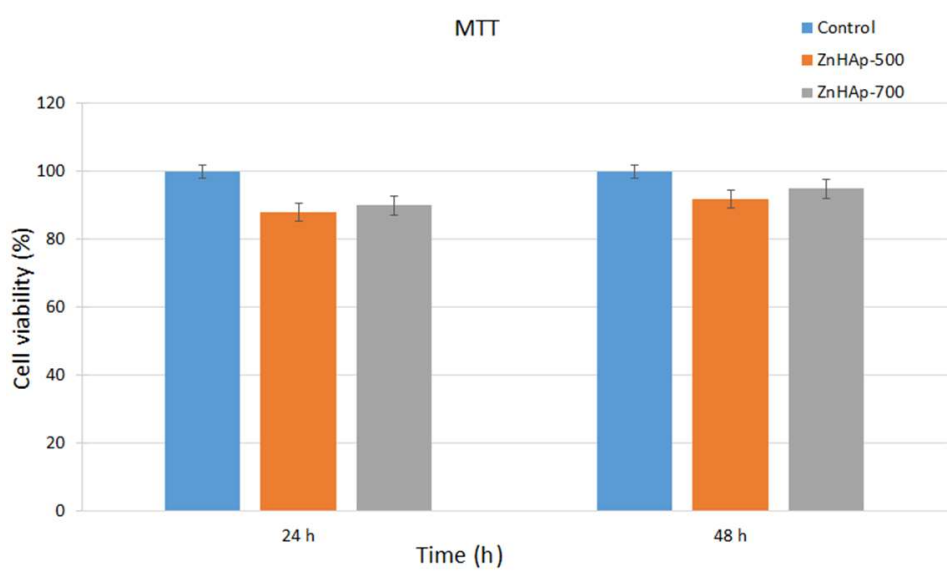

Figure 8. Cell viability of the HeLa cells for incubation times of 24 and $48 \mathrm{~h}$ in the presence of ZnHAp-500 and ZnHAp-700 layers.

\subsection{Antimicrobial Activity}

The antimicrobial activity of the HAp and ZnHAp layers was assessed by studying the cell viability of two significant microbial strains in the presence of the layers.

The results of the antimicrobial activity of the Hap, ZnHAp-500, and AnHAp-700 layers against the two most common microorganisms associated with hospital-related infections are presented in Table 1.

Table 1. Qualitative screening of the antimicrobial activities of the HAp, ZnHAp-500, and ZnHAp-700 layers against Candida albicans ATCC 10231 and Staphylococcus aureus ATCC 25923.

\begin{tabular}{|c|c|c|c|c|c|c|c|c|}
\hline \multirow{2}{*}{ Sample } & \multicolumn{4}{|c|}{ Candida albicans ATCC 10231} & \multicolumn{4}{|c|}{ Staphylococcus aureus ATCC 25923} \\
\hline & $8 \mathrm{~h}$ & $24 \mathrm{~h}$ & $32 \mathrm{~h}$ & $48 \mathrm{~h}$ & $8 \mathrm{~h}$ & $24 \mathrm{~h}$ & $32 \mathrm{~h}$ & $48 \mathrm{~h}$ \\
\hline HAp & \pm & \pm & \pm & + & \pm & + & + & + \\
\hline ZnHAp-500 & + & ++ & +++ & +++ & + & ++ & +++ & +++ \\
\hline ZnHAp-700 & ++ & +++ & +++ & ++++ & ++ & +++ & ++++ & ++++ \\
\hline
\end{tabular}


The results of the qualitative screening have revealed that all of the tested layers had an inhibitory effect on the tested microbial strains. On the other hand, it was emphasized that the ZnHAp-700 layers were the most efficient in inhibiting both C. albicans and S. aureus bacterial cells.

The microbial strains chosen for the experiments are some of the most common microorganisms responsible for frequent infections in daily life. The effect of HAp coated Si discs, and ZnHAp-500 and ZnHAp-700 layers against the cell development of the C. albicans and S. aureus microbial strains are presented in Figure 9. The results of the cell viability studies revealed that a small effect on C. albicans and S. aureus cells growth was noticed for the HAp coated Si discs. The cell growth of the tested microbial strains in the presence of HAp coated Si discs was comparable with the results obtained for the cell growth of the control, but smaller. Furthermore, the cytotoxicity assay of the ZnHAp layers against the development of the fungal cells of Candida albicans revealed that even after $8 \mathrm{~h}$ of incubation, the fungal cell growth was inhibited and diminished with time. The results emphasized that both the ZnHAp-500 and ZnHAp-700 layers considerably inhibited the cell growth of the fungal cells of C. albicans at all of the tested time intervals. Moreover, the results suggested that the ZnHAp-700 layers exhibited a greater cytotoxic effect on the fungal cell viability than the ZnHAp-500 layers. The most significant cell growth inhibition in the case of the $C$. albicans fungal cells was obtained after $48 \mathrm{~h}$ of incubation for both the ZnHap-500 and ZnHAp-700 samples. Furthermore, the cytotoxicity of the ZnHAp layers was also investigated in the case of $S$. aureus bacterial cells. The results of the antibacterial assay highlighted that both ZnHAp layers presented a strong cytotoxic effect on the $S$. aureus bacterial cells growth. Studies regarding the cell viability of the $S$. aureus bacterial cells in the presence of the ZnHAp-500 layers revealed that the samples inhibited cell growth even after a short period of $8 \mathrm{~h}$ of incubation. The cytotoxic assays suggested that the inhibition of the cell growth was time depended, and the best cytotoxic effect was registered after $48 \mathrm{~h}$ of incubation. Similar results were obtained in the case of the toxicity of the ZnHAp-700 layers against bacterial cell growth. The results emphasized that the ZnHAp-700 layers showed a strong inhibitory effected against the cell growth of the $S$. aureus bacterial cells, even after $8 \mathrm{~h}$ of incubation. Moreover, the cytotoxic effect of ZnHAp-700 on the cell growth of the S. aureus bacterial cells was greater than the cytotoxic effect of the ZnHAp-500 layers. Nevertheless, both samples proved to exhibit strong antimicrobial properties and had a good inhibitory effect on the cell growth of the tested microorganism.
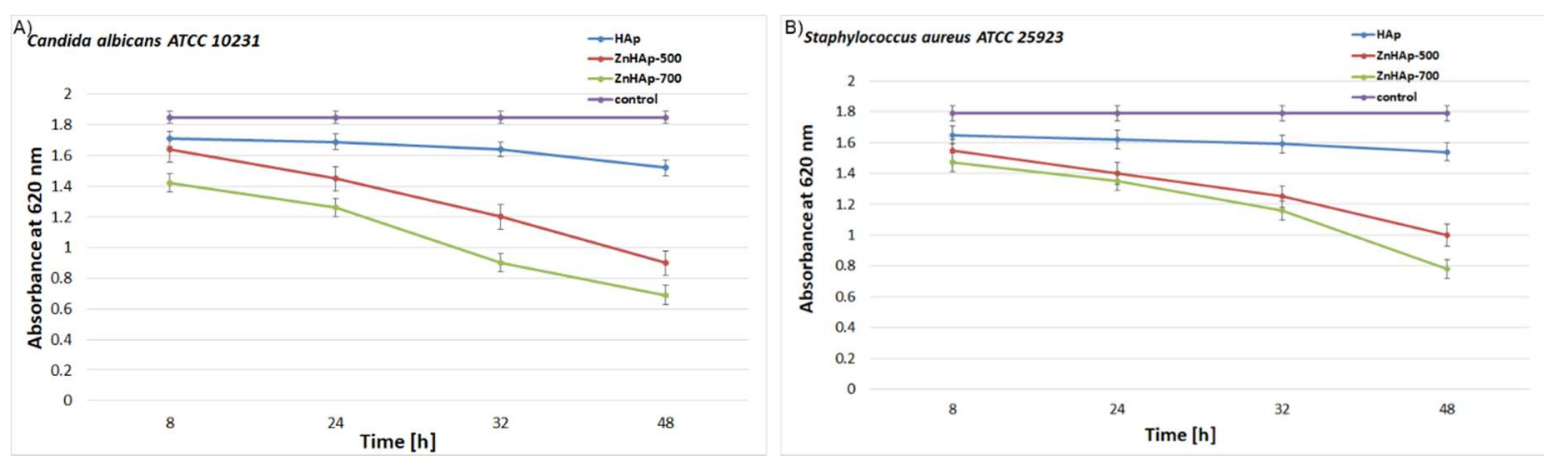

Figure 9. Cell viability assays: (A) Candida albicans ATCC 10231 cell development for 8, 24, 32, and $48 \mathrm{~h}$ in the presence of HAp and ZnHAp layers; (B) Staphylococcus aureus ATCC 25923 cell development for $8,24,32$, and $48 \mathrm{~h}$ in the presence of ZnHAp composite layers.

The adherence and development of the C. albicans and S. aureus microbial cells after 24 and $48 \mathrm{~h}$ of incubation on the surface of the ZnHAp-500 and ZnHAp-700 layers were investigated using scanning electron microscopy (SEM). Images of the adherence and development of $C$. albicans fungal cells and $S$. aureus bacterial cells on the surfaces of the Si substrate and the ZnHAp-500 and ZnHAp-700 layers obtained from the SEM investigations are presented in Figures 10 and 11A-F. 


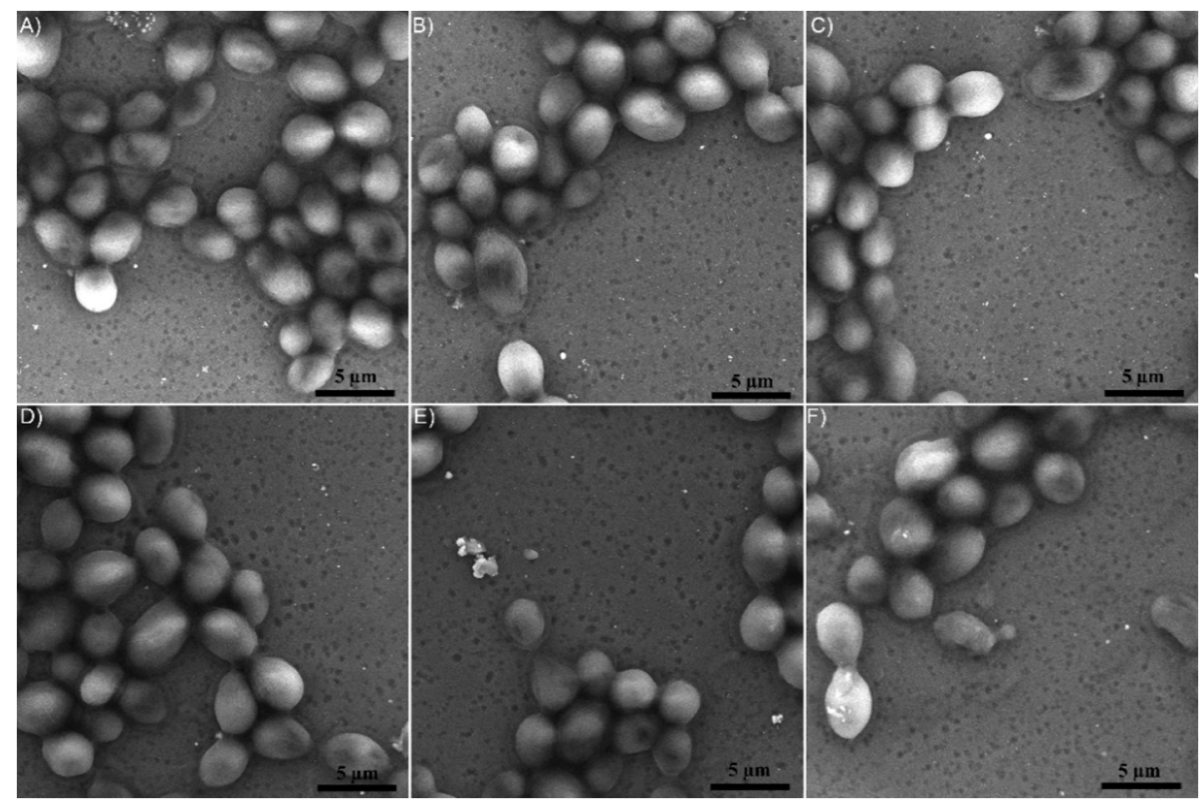

Figure 10. SEM images of $C$. albicans ATCC 10231 cell development on HAp coated Si discs used as the control (A,D), and the ZnHAp-500 and ZnHAp-700 layers after $24 \mathrm{~h}(\mathbf{B}, \mathbf{C})$ and $48 \mathrm{~h}$ (E,F) of incubation.

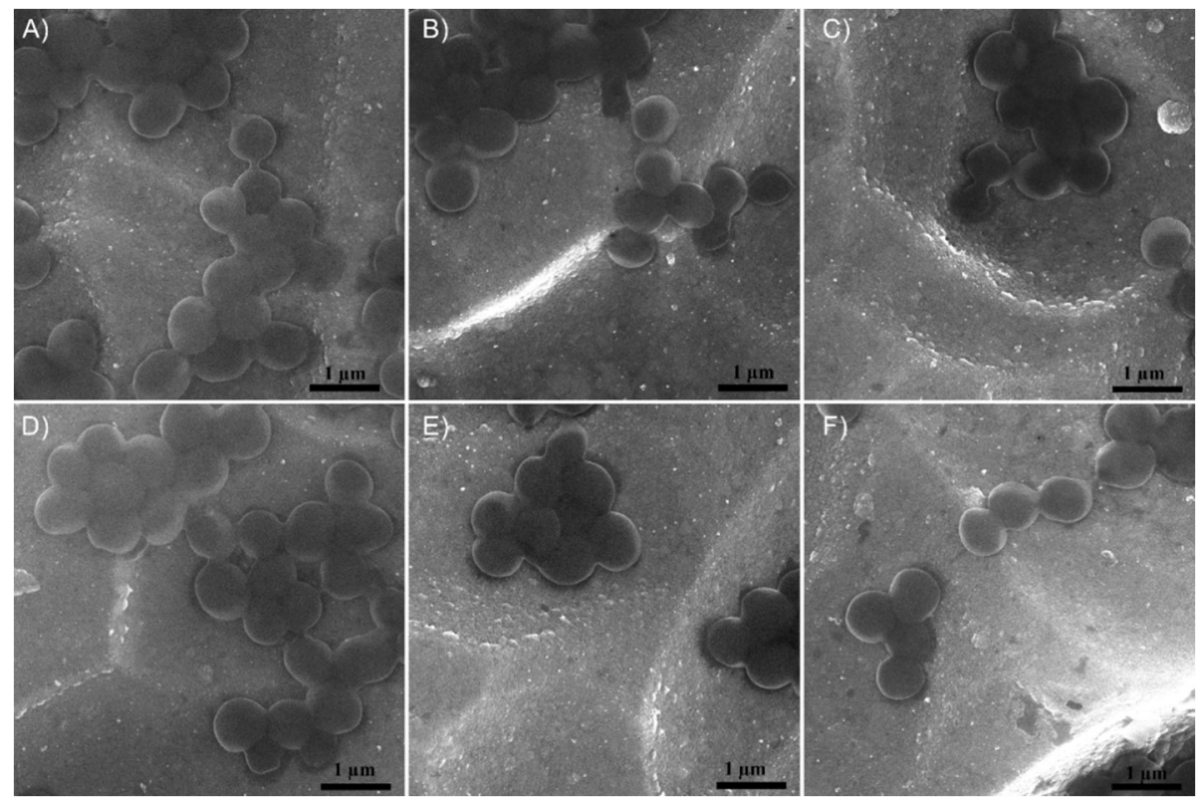

Figure 11. SEM images of Staphylococcus aureus ATCC 25923 cell development on HAp coated the Si discs used as the control (A,D), and the ZnHAp-500 and ZnHAp-700 layers after $24 \mathrm{~h}(\mathbf{B}, \mathbf{C})$ and $48 \mathrm{~h}$ $(\mathrm{E}, \mathrm{F})$ of incubation.

The SEM visualization highlighted that the morphology of the fungal cells was characteristic to the C. albicans fungal strain, with an ovaloid "yeast" shape and sizes ranging from 2.8 to $4.3 \mu \mathrm{m}$. More than that, the SEM investigations revealed that the fungal cells had a good adherence on the HAp coated Si discs after 24 and $48 \mathrm{~h}$ of incubation. The images also reflect that the ZnHAp-500 and ZnHAp-700 layers presented a good inhibitory effect against the development of C. albicans fungal cells. As it can be seen from the SEM images, a better antifungal activity was observed in the case of the ZnHAp-700 layers for both of the tested intervals (Figure 10C,F).

The number of the adhered Candida albicans fungal cells on the surface of the HAp, ZnHAp-500, and ZnHAp-700 layers was quantified by performing the count of cells on three different areas of 
$25 \mu \mathrm{m} \times 25 \mu \mathrm{m}$ of the investigated samples. The results revealed that after $24 \mathrm{~h}$ of incubation for the HAp sample, an average of $40 \pm 4$ bacterial cells were found, while for the ZnHAp-500 and ZnHAp-700 layers, an average of $24 \pm 4$ cells were found. More than that, after $48 \mathrm{~h}$ of incubation, the quantitative results of the cell counting emphasized that for the HAp samples, an average of $33 \pm 3$ bacterial cells were identified on the surface of the samples. In the case of ZnHAp-500, we identified approximately $18 \pm 2$ fungal cells, while for the ZnHAp-700 layers, the counting had revealed only approximately $15 \pm 2$ fungal cells on the investigated surfaces.

The SEM observation in the case of the HAp deposited on the Si discs and the ZnHAp layers incubated for 24 and $48 \mathrm{~h}$ with Staphylococcus aureus ATCC 25923 microbial suspensions, revealed that on the surface of the investigated samples, round-shaped bacterial cells with sizes between 0.5 and $0.8 \mu \mathrm{m}$, typical to S. aureus bacterial cells, were found (Figure 11A-F). SEM images in this case that in this case, the HAp deposited Si discs only slightly affected the adherence and development of the $S$. aureus bacterial cells (Figure 11A,D), and presented a small inhibitory activity towards the tested strain after both 24 and $48 \mathrm{~h}$ of incubation. Moreover, the SEM images indicated that both ZnHAp layers had a significant antibacterial activity against $S$. aureus ATCC 25923. Even though both of the ZnHAp layers had an inhibitory effect on the development of the bacterial cell, a stronger antibacterial activity was observed in the case of the ZnHAp-700 layers (Figure 11C,F). The SEM images accentuated that for both time intervals, the ZnHAp-700 layer had a strong inhibitory effect on the adherence and development of the $S$. aureus bacterial cells. Nonetheless, a more substantial antibacterial activity of the ZnHAp-700 layers has been identified after $48 \mathrm{~h}$ of incubation.

Quantitative investigations by counting the number of $S$. aureus bacterial cells adhered on the surface of HAp, and the ZnHAp-500 and ZnHAp-700 layers were performed on three different areas of $5 \mu \mathrm{m} \times 5 \mu \mathrm{m}$ of the investigated samples. The results have highlighted that in the case of the HAp coating on a surface of $5 \mu \mathrm{m} \times 5 \mu \mathrm{m}$, approximately $30 \pm 2$ bacterial cells were counted after $24 \mathrm{~h}$ of incubation. Moreover, after $24 \mathrm{~h}$ of incubation, a drastically reduced number of bacterial cells were obtained in the case of the ZnHAp-700 layers, which had only $12 \pm 2$ bacterial cells, comparatively with the ZnHAp-500 layers, which allowed for the development of approximately $20 \pm 3$ bacterial cells. Furthermore, after $48 \mathrm{~h}$ of incubation, the results of the cell counting showed a decrease in the number the bacterial cells that adhered on the ZnHAp-500 sample to $15 \pm 4$. A small decrease after 48 $h$ of incubation was also observed in the case of the ZnHAp-700 layers. The counted cells in this case were $10 \pm 2$.

\subsection{Discussions}

This research aimed at creating a new material with effective antimicrobial properties that could lead to a decrease of infections in implants/bone. Zinc-doped hydroxyapatite layers could help in the prevention and treatment of perioperative and intraoperative bone infections. According to previous studies [19,53-55], the zinc ion substitution in hydroxyapatite includes different aspects regarding the mechanism of inhibition of microbial growth. By bonding with the functional groups and increasing the permeability of the cells, the zinc ions cause the deterioration of the cell membranes.

In accordance with the existing literature, the most common elements used for hydroxyapatite doping are silver and zinc. It is known that silver is used in HAp doping for its antimicrobial properties, while the zinc content can lead also to increased biocompatible properties of the coating, and may contribute to the wound healing process [17,55-59].

The quality of the coatings is heavily influenced by the method of achieving it. The method of surface coating that we proposed in this study is effective because of its low costs and the fact that the most important parameters in the layers acquisition (such as solution stability) are easy to control. In our present study, the sol-gel method was used to synthesize the gel used to prepare the thin films using the sol-gel spin coating method. According to previous studies [56], the gels consist of a solid skeleton that encloses the liquid phase or solvent. The resulting sol-gel solution was evaluated from

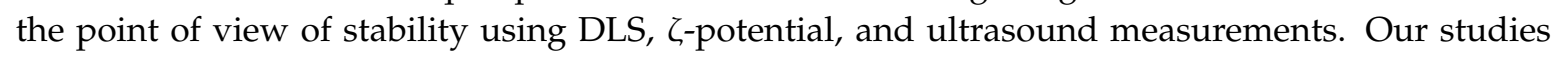


regarding the zeta potential value of the ZnHAp nanoparticles in the solution were in good agreement with the previous studies [56]. In previous studies conducted by Fahami et al. [56], it was shown that the $\zeta$-potential of the HAp suspension doped with chlorine and fluorine had a negative value. Moreover, they showed that solutions that have a negative $\zeta$-potential favor osteointegration, apathy nucleation, and bone regeneration. The stability of the ZnHAp undiluted suspension was established using an ultrasound-based technique. The ultrasound measurements gave us clear information about the stability of the suspensions. It is well known that other techniques that allow us to have information on the stability and aggregation of suspended particles require sufficiently diluted suspensions with a solids content of less than $1 \mathrm{vol} \%$. Traditional techniques, despite their popularity, cannot be applied to dense or opaque suspensions. Thus, ultrasound-based technique can provide clear information, regardless of the degree of dispersion or the opacity of the suspensions, as the acoustic fields can serve as an alternative test for the dispersal state. Thus, the ultrasound measurements used to study the ZnHAp solution obtained using the sol-gel method showed a good stability, certified by the calculated stability coefficient. The stability coefficient ZnHAp undiluted suspension showed a relatively stable suspension compared to pure water. The value of the stability coefficient of the ZnHAp solution (undiluted suspension) obtained using the sol-gel method was equal to $0.0152(1 / \mathrm{s})$ vs. 0 (the coefficient of stability of the pure water).

The results presented in this study are in agreement with previous studies that have shown a good biocompatibility of the ZnHAp on human osteoblast cells MG-63 [59], mesenchymal stem cells derived from human adipose (MSCs) [32], and MRC-5 fibroblast cells [33]. Furthermore, Thian et al. [32], in their studies on "zinc-substituted hydroxyapatite: a biomaterial with enhanced bioactivity and antimicrobial properties", demonstrated that the presence of $\mathrm{Zn}^{2+}$ ions in the structure of the hydroxyapatite stimulated the bioactivity of HAp. On the other hand, previous research [32,55-59] provides information on the antimicrobial activity of ZnHAp against various pathogens. Radovanović et al. [33] showed that E. coli, S. aureus, P. aeruginosa, and C. albicans were susceptible to Zn-HA, and the degree of reduction was increased when the zinc ion content increased. Moreover, Tank et al. [59] showed that $S$. aureus was the most sensitive strain. Finally, we can say that the studies developed in this paper revealed that coatings based on ZnHAp have the ability to improve the biocompatibility of medical implants.

\section{Conclusions}

The bio layers were prepared from ZnHAp stable gels using the sol-gel spin coating method. ZnHAp in gel suspensions were evaluated by DLS, $\zeta$-potential, and ultrasound measurements. The stability of the ZnHAp suspensions was demonstrated by both the $\zeta$-potential and ultrasound measurements. As observed by the SEM analysis, the zinc-doped hydroxyapatite gel deposited on the Si substrate had a good crystallinity after heat treatment. The surface of the two samples (ZnHAp-500 and ZnHAp-700) analyzed was homogeneous, without showing breaks.

The cytotoxicity of the ZnHAp layers obtained using the sol-gel spin coating method were investigated using a HeLa cell line. The biocompatibility assays evidenced that the ZnHAp composite layers did not present any toxicity towards the HeLa cells.

The in vitro antimicrobial studies indicated a significantly reduced number of both $S$. aures and C. albicans microbial cells on the surface of the ZnHAp layers when compared to the HAp coated Si surface.

The results of this study also emphasized that the annealing temperature of the coatings had a slight influence on the biological properties of the samples. The cytotoxic assays against the microbial cells showed that ZnHAp-700 exhibited a stronger toxicity towards the cells' development for both S. aures and C. albicans cells. Overall, it was concluded that the ZnHAp layers possess a good biocompatibility and also exhibit strong antimicrobial properties, making them suitable for use in biomedical applications. The results obtained in this study could be extremely useful in the future development of antimicrobial devices with biocompatible properties. 
Author Contributions: Conceptualization, D.P. and M.V.P.; Methodology, D.P.; Software, M.V.P.; Validation, D.P., M.M.-H., and M.V.P.; Formal Analysis, D.P., S.L.I., M.V.P., M.M.-H., and N.B.; Investigation, D.P., S.L.I., M.V.P., and N.B.; Resources, D.P., S.L.I., M.V.P., M.M.-H., and N.B.; Data Curation, D.P., S.L.I., and M.V.P.; Writing-Original Draft Preparation, D.P., S.L.I., M.V.P., M.M-H., and N.B.; Writing-Review and Editing, D.P., S.L.I., and M.V.P.; Visualization, D.P., S.L.I., M.V.P., M.M.-H., and N.B.; Supervision, M.V.P., M.M.H., and N.B.; Project Administration, D.P.; Funding Acquisition, D.P.

Funding: This research was (partially) supported by Romanian Ministry of Research and Innovation PCCDI-UEFISCDI (project number PN-III-P1-1.2-PCCDI-2017-0629/contract no. 43PCCDI/2018), and the Romanian Ministry of Research and Innovation (Core Program 21N/2019).

Acknowledgments: We thank Annie Richard and Audrey Sauldubois from the "Centre de Microscopie Electronique" of the University of Orléans for assistance in the SEM data acquisition.

Conflicts of Interest: The authors declare no conflict of interest.

\section{References}

1. Darouiche, R.O. Current concepts-Treatment of infections associated with surgical implants. N. Engl. J. Med. 2004, 350, 1422-1429. [CrossRef] [PubMed]

2. Vallet-Regi, M.; Arcos, D. Biomimetic Nanoceramics in Clinical Use: From Materials to Applications, 1st ed.; Royal Society of Chemistry: Cambridge, UK, 2008.

3. Prodan, A.M.; Beuran, M.; Turculet, C.S.; Popa, M.; Andronescu, E.; Bleotu, C.; Raita, S.M.; Soare, M.; Lupescu, O. In vitro evaluation of glycerol coated iron oxide nanoparticles in solution. Rom. Biotechnol. Lett. 2018, 23, 13901-13908.

4. Kojic, E.M.; Darouiche, R.O. Candida infections of medical devices. Clin. Microbiol. Rev. 2004, 17, $255-267$. [CrossRef] [PubMed]

5. Chandra, J.; Guangyin, Z.; Ghannoum, M.A. Fungal biofilms and antimycotics. Curr. Drug Targets 2005, 6, 887-894. [CrossRef] [PubMed]

6. Von Eiff, C.; Jansen, B.; Kohnen, W. Infections associated with medical devices: Pathogenesis, management and prophylaxis. Drugs 2005, 65, 179-214. [CrossRef] [PubMed]

7. Predoi, D.; Iconaru, S.L.; Buton, N.; Badea, M.L.; Marutescu, L. Antimicrobial activity of new materials based on lavender and basil essential oils and hydroxyapatite. Nanomaterials 2018, 8, 291. [CrossRef] [PubMed]

8. Furko, M.; Jiang, Y.; Wilkins, T.; Balázsi, C. Development and characterization of silver and zinc doped bioceramic layer on metallic implant materials for orthopedic application. Ceram. Int. 2016, 42, 4924-4931. [CrossRef]

9. Bosetti, M.; Massé, A.; Tobin, E.; Cannas, M. Silver coated materials for external fixation devices: In vitro biocompatibility and genotoxicity. Biomaterials 2002, 23, 887-892. [CrossRef]

10. Jung, W.K.; Koo, H.C.; Kim, K.W.; Shin, S.; Kim, S.H.; Park, Y.H. Antibacterial activity and mechanism of action of the silver ion in Staphylococcus aureus and Escherichia coli. Appl. Environ. Microbiol. 2008, 74, 2171-2178. [CrossRef] [PubMed]

11. Schierholz, J.M.; Lucasj, L.J.; Rump, A. Efficacy of silver-coated medical devices. J. Hosp. Infect. 1998, 40, 257-262. [CrossRef]

12. Huang, Y.; Zhang, X.; Qiao, H.; Hao, M.; Zhang, H.; Xu, Z.; Zhang, X.; Pang, X.; Lin, H. Corrosion resistance and cytocompatibility studies of zinc-doped fluorohydroxyapatite nanocomposite coatings on titanium implant. Ceram. Int. 2016, 42, 1903-1915. [CrossRef]

13. Kolmas, J.; Groszyk, E.; Kwiatkowska-Róhycka, D. Substituted hydroxyapatites with antibacterial properties. BioMed Res. Int. 2014, 2014, 178123. [CrossRef] [PubMed]

14. Kurtjak, M.; Aničić, N.; Vukomanovicć, M. Inorganic nanoparticles: Innovative tools for antimicrobial agents. In Antibacterial Agents; Kumavath, R.N., Ed.; IntechOpen: London, UK, 2017.

15. Liedtke, J.; Vahjen, W. In vitro antibacterial activity of zinc oxide on a broad range of reference strains of intestinal origin. Vet. Microbiol. 2012, 160, 251-255. [CrossRef] [PubMed]

16. Iconaru, S.L.; Prodan, A.M.; Turculet, C.S.; Beuran, M.; Ghita, R.V.; Costescu, A.; Groza, A.; Chifiriuc, M.C.; Chapon, P.; Gaiaschi, S.; et al. Enamel based composite layers deposited on titanium substrate with antifungal activity. J. Spectrosc. 2016, 2016, 4361051. [CrossRef] 
17. Groza, A.; Ciobanu, C.S.; Popa, C.L.; Iconaru, S.L.; Chapon, P.; Luculescu, C.; Ganciu, M.; Predoi, D. Structural properties and antifungal activity against Candida albicans biofilm of different composite layers based on $\mathrm{Ag} / \mathrm{Zn}$ doped hydroxyapatite-polydimethylsiloxanes. Polymers 2016, 8, 131. [CrossRef]

18. Ciobanu, C.S.; Massuyeau, F.; Constantin, L.V.; Predoi, D. Structural and physical properties of antibacterial Ag-doped nano-hydroxyapatite synthesized at $100{ }^{\circ} \mathrm{C}$. Nanoscale Res. Lett. 2011, 6, 613. [CrossRef] [PubMed]

19. Predoi, D.; Iconaru, S.L.; Deniaud, A.; Chevallet, M.; Michaud-Soret, I.; Buton, N.; Prodan, A.M. Textural, structural and biological evaluation of hydroxyapatite doped with zinc at low concentrations. Materials 2017, 10, 229. [CrossRef] [PubMed]

20. Popa, C.L.; Deniaud, A.; Michaud-Soret, I.; Guégan, R.; Motelica-Heino, M.; Predoi, D. Structural and biological assessment of zinc doped hydroxyapatite nanoparticles. J. Nanomater. 2016, 2016, 1062878. [CrossRef]

21. Ciobanu, C.S.; Popa, C.L.; Predoi, D. Sm:HAp Nanopowders present antibacterial activity against Enterococcus faecalis. J. Nanomater. 2014, 2014, 780686. [CrossRef]

22. Zebarjad, S.M.; Sajjadi, S.A.; Ebrahimi Sdrabadi, T.; Sajjadi, S.A.; Yaghmaei, A.; Naderi, B. A Study on mechanical properties of PMMA/hydroxyapatite nanocomposite. Engineering 2011, 3, 795-801. [CrossRef]

23. Prasadh, S.; Wong, R.C.W. Unraveling the mechanical strength of biomaterials used as a bone scaffold in oral and maxillofacial defects. Oral Sci. Int. 2018, 15, 48-55. [CrossRef]

24. Predoi, D.; Iconaru, S.L.; Predoi, M.V. Bioceramic layers with antifungal properties. Coatings 2018, 8, 276. [CrossRef]

25. Turculet, C.S.; Prodan, A.M.; Negoi, I.; Teleanu, G.; Popa, M.; Andronescu, E.; Beuran, M.; Stanciu, G.A.; Hristu, R.; Badea, M.L.; et al. Preliminary evaluation of the antifungal activity of samarium doped hydroxyapatite thin films. Rom. Biotechnol. Lett. 2018, 23, 13928-13932.

26. Andronescu, E.; Iordache, F.; Ciobanu, C.S.; Badea, M.L.; Costescu, A.; Prodan, A. Optical properties of bioactive europium doped hydroxyapatite (HAp:Eu $\left.{ }^{3+}\right)$. Optoelectron. Adv. Mat. 2015, 9, 1155-1159.

27. Negrila, C.C.; Predoi, M.V.; Iconaru, S.L.; Predoi, D. Development of Zinc-doped hydroxyapatite by sol-gel method for medical applications. Molecules 2018, 23, 2986. [CrossRef] [PubMed]

28. Johal, K.K. In vivo response of strontium and zinc-based ionomeric cement implants in bone. J. Mater. Sci. Mater. Med. 2002, 13, 375-379. [CrossRef] [PubMed]

29. Yamaguchi, M. Role of zinc in bone formation and bone resorption. J. Trace Elem. Exp. Med. 1998, 11, 119-135. [CrossRef]

30. Ohtsu, N.; Kakuchi, Y.; Ohtsuki, T. Antibacterial effect of zinc oxide/hydroxyapatite coatings prepared by chemical solution deposition. Appl. Surf. Sci. 2018, 445, 596-600. [CrossRef]

31. Iconaru, S.L.; Prodan, A.M.; Buton, N.; Predoi, D. Structural characterization and antifungal studies of zinc-doped hydroxyapatite coatings. Molecules 2017, 22, 604. [CrossRef] [PubMed]

32. Thian, E.S.; Konishi, T.; Kawanobe, Y.; Lim, P.N.; Choong, C.; Ho, B.; Aizawa, M. Zinc-substituted hydroxyapatite: A biomaterial with enhanced bioactivity and antibacterial properties. J. Mater. Sci. Mater. Med. 2013, 24, 437-445. [CrossRef] [PubMed]

33. Radovanović, Ž.; Veljović, D.; Jokić, B.; Dimitrijević, S.; Bogdanović, G.; Kojić, V.; Petrović, R.; Janaćković, D. Biocompatibility and antimicrobial activity of zinc(II)-doped hydroxyapatite, synthesized by a hydrothermal method. J. Serb. Chem. Soc. 2012, 77, 1787-1798. [CrossRef]

34. Adamiak, B.; Wiatrowski, A.; Domaradzki, J.; Kaczmarek, D.; Wojcieszak, D.; Mazur, M. Preparation of multicomponent thin films by magnetron co-sputtering method: The Cu-Ti case study. Vacuum 2019, 161, 419-428. [CrossRef]

35. Rajendra Kumar, R.T.; Karunagaran, B.; Senthil Kumar, V.; Jeyachandran, Y.L.; Mangalaraj, D.; Narayandass, S.K. Structural properties of $\mathrm{V}_{2} \mathrm{O}_{5}$ thin films prepared by vacuum evaporation. Mater. Sci. Semicond. Process. 2003, 6, 543. [CrossRef]

36. Wang, X.; Shi, F.; Gao, X.; Fan, C.; Huang, W.; Feng, X. A sol-gel dip/spin coating method to prepare titanium oxide films. Thin Solid Films 2013, 548, 34-39. [CrossRef]

37. Calnan, S.; Upadhyaya, M.H.; Dann, E.S.; Thwaites, J.M.; Tiwari, N.A. Effects of target bias voltage on indium tin oxide films deposited by high target utilisation sputtering. Thin Solid Films 2007, 515, 8500-8504. [CrossRef] 
38. Yuen, C.; Yu, S.F.; Leong, E.S.P.; Lau, S.P.; Pita, K.; Yang, H.Y.; Chen, T.P. Room temperature deposition of p-type arsenic doped $\mathrm{ZnO}$ polycrystalline films by laser-assist filtered cathodic vacuum arc technique. J. Appl. Phys. 2007, 101, 094905. [CrossRef]

39. Gurav, K.V.; Patil, U.M.; Shin, S.W.; Pawar, S.M.; Kim, J.H.; Lokhande, C.D. Morphology evolution of ZnO thin films from aqueous solutions and their application to liquefied petroleum gas (LPG) sensor. J. Alloy. Compd. 2012, 525, 1-7. [CrossRef]

40. Jamesh, M.; Kumar, S.; Sankara Narayanan, T.S.N. Electrodeposition of hydroxyapatite coating on magnesium for biomedical applications. J. Coat. Technol. Res. 2012, 9, 495-502. [CrossRef]

41. Hornberger, H.; Virtanen, S.; Boccaccini, A.R. Biomedical coatings on magnesium alloys-A review. Acta Biomater. 2012, 8, 2442-2455. [CrossRef] [PubMed]

42. Wen, C.E.; Xu, W.; Hu, W.Y.; Hodgson, P.D. Hydroxyapatite/titania sol-gel coatings on titanium-zirconium alloy for biomedical applications. Acta Biomater. 2007, 3, 403-410. [CrossRef] [PubMed]

43. Kakimoto, M.-A.; Suzuki, M.-A.; Konishi, T.; Imai, Y.; Iwamoto, M.; Hino, T. Preparation of mono- and multilayer films of aromatic polyimides using Langmuir-Blodgett technique. Chem. Lett. 1986, 15, 823-826. [CrossRef]

44. Tsay, C.Y.; Fan, K.S.; Wang, Y.W.; Chang, C.J.; Tseng, Y.K.; Lin, C.K. Transparent semiconductor zinc oxide thin films deposited on glass substrates by sol-gel process. Cermic. Int. 2010, 36, 1791-1795. [CrossRef]

45. Emslie, A.G.; Bonner, F.T.; Peck, L.G. Flow of a viscous liquid on a rotating disk. J. Appl. Phys. 1958, 29, 858-862. [CrossRef]

46. Motelica-Heino, M.; Donard, O.F. Comparison of UV and IR laser ablation ICP-MS on silicate reference materials and implementation of normalisation factors for quantitative measurements. Geostand. Geoanal. Res. 2001, 25, 345-359. [CrossRef]

47. ASTM E2149-13a Standard Test Method for Determining the Antimicrobial Activity of Antimicrobial Agents under Dynamic Contact Conditions; ASTM International: West Conshohocken, PA, USA, 2013.

48. Fuchs, A.V.; Ritz, S.; Pütz, S.; Mailänder, V.; Landfester, K.; Ziener, U. Bioinspired phosphorylcholine containing polymer films with silver nanoparticles combining antifouling and antibacterial properties. Biomater. Sci. 2013, 1, 470-477. [CrossRef]

49. Ciobanu, C.S.; Iconaru, S.L.; Gyorgy, E.; Radu, M.; Costache, M.; Dinischiotu, A.; Le Coustumer, P.; Lafdi, K.; Predoi, D. Biomedical properties and preparation of iron oxide-dextran nanostructures by MAPLE technique. Chem. Cent. J. 2012, 6, 17. [CrossRef] [PubMed]

50. Egelhaaf, S.U.; Wehrli, E.; Muller, M.; Adrian, M.; Schurtenberger, P. Determination of the size distribution of lecithin liposomes: A comparative study using freeze fracture, cryoelectron microscopy and dynamic light scattering. J. Microsc. 1996, 184, 214-228. [CrossRef]

51. Xu, G.; Aksay, I.A.; Groves, J.T. Continuous crystalline carbonate apatite thin films. A Biomimetic approach. J. Am. Chem. Soc. 2001, 123, 2196-2203. [CrossRef] [PubMed]

52. Jokanovic, V.; Uskokovic, D. Calcium hydroxyapatite thin films on titanium substrates prepared by ultrasonic spray pyrolysis. Mater. Trans. 2005, 46, 228-235. [CrossRef]

53. Anwar, A.; Akbar, S.; Sadiqa, A.; Kazmi, M. Novel continuous flow synthesis, characterization and antibacterial studies of nanoscale zinc substituted hydroxyapatite bioceramics. Inorg. Chim. Acta 2016, 453, 16-22. [CrossRef]

54. Chen, X.; Tang, Q.L.; Zhu, Y.J.; Zhu, C.L.; Feng, X.P. Synthesis and antibacterial property of zinc loaded hydroxyapatite nanorods. Mater. Lett. 2012, 89, 233-235. [CrossRef]

55. Ren, F.; Xin, R.; Ge, X.; Leng, Y. Characterization and structural analysis of zinc-substituted hydroxyapatites. Acta Biomater. 2009, 5, 3141-3149. [CrossRef] [PubMed]

56. Ben-Nissan, B.; Choi, A.H. Sol-gel production of bioactive nano-coatings for medical applications. Part 1: An introduction. Nanomedicine 2006, 1, 311-319. [CrossRef] [PubMed]

57. Fahami, A.; Beall, G.W.; Betancourt, T. Synthesis, bioactivity and zeta potential investigations of chlorine and fluorine substituted hydroxyapatite. Mater. Sci. Eng. C Mater. Biol. Appl. 2016, 59, 78-85. [CrossRef] [PubMed] 
58. Zhang, J. Biocompatibility and anti-bacterial activity of $\mathrm{Zn}$-containing $\mathrm{HA} / \mathrm{TiO}_{2}$ hybrid coatings on $\mathrm{Ti}$ substrate. J. Hard. Tissue Biol. 2013, 22, 311-318. [CrossRef]

59. Tank, K.P.; Chudasama, K.S.; Thaker, V.S.; Joshi, M.J. Pure and zinc doped nano-hydroxyapatite: Synthesis, characterization, antimicrobial and hemolytic studies. J. Cryst. Growth 2014, 401, 474-479. [CrossRef] 